University of Nebraska - Lincoln

DigitalCommons@University of Nebraska - Lincoln

Winter 10-30-2021

\title{
Usage and Usefulness of N-LIST E-Resources among Postgraduate Students of Government Aided Colleges in Punjab, India
}

Subhajit Panda

Chandigarh University, Mohali, Punjab, suvapanda007@gmail.com

Follow this and additional works at: https://digitalcommons.unl.edu/libphilprac

Part of the Information Literacy Commons, Scholarly Communication Commons, and the Scholarly Publishing Commons

Panda, Subhajit, "Usage and Usefulness of N-LIST E-Resources among Postgraduate Students of Government Aided Colleges in Punjab, India" (2021). Library Philosophy and Practice (e-journal). 6548. https://digitalcommons.unl.edu/libphilprac/6548 


\title{
Usage and Usefulness of N-LIST E-Resources among Postgraduate Students of Government Aided Colleges in Punjab, India
}

\author{
Subhajit Panda \\ Assistant Librarian, Chandigarh University, Mohali, Punjab (India) \\ Email: suvapanda007@gmail.com
}

\begin{abstract}
With the emergence of information technology, users' information-seeking behaviour (ISB) and information preferences alter with a great space. The advancement of ICT infrastructure leads to increase demand and widespread use of e-resources. The Internet and the Web are constantly influencing the development of new modes of scholarly communication; their potential for delivering goods is quite vast, as they overcome the geographical limitations associated with print media. Now users can access e-resources on their desktops. But in India, the constraints on sufficient access to e-resources lay on the financial barrier \& high subscription charges. To overcome it and prioritize the college academic community, the UGC-MHRD initiated the N-LIST consortium to provide selected e-journals and e-books to the registered colleges in India. The present study targeted the postgraduate students in Government aided colleges of Punjab to examine the awareness and use of N-LIST e-resources, its purposes of usage, level of satisfaction and problems faced while accessing N-LIST e-resources. For this purpose, a well-structured questionnaire was prepared with the help of Google form as a tool for data collection. The study findings reveal that the majority of respondents are aware of N-LIST e-resources, while its usage is not up to the mark. Based on the conclusions, it recommends that college libraries should conduct hands-on training programmes \& workshops besides outreach \& orientation programmes to maximize the usage of N-LIST e-resources.
\end{abstract}

Keywords: E-Resources, Library Consortium, N-LIST, Postgraduate Students, Government Aided Colleges, Punjab

\section{Introduction:}

In terms of enrollment, India has the third-largest educational system after China and the United States (The World Bank, 2020a), but the per capita GDP of India (1,900.7 US\$) is much much lower than the two (China: 10,500.4 US\$ and United States: 63,543.6 US\$) (The World Bank, 2020b). All educational institutions in India are facing fund constraints for most of the international journal subscriptions due to the present economic condition of our country and the exponential increase in subscription costs (particularly those published by for-profit publishers). In the case of the colleges, that run Post-graduation and Doctoral programs lack the funds to purchase 
international journals and well-known magazines. This leads to the emergence of the concept of resource sharing and consortium. N-LIST is one of the consortia models which provides access to selected e-resources for students, researchers and faculty from colleges and other beneficiary institutions through a server installed at the INFLIBNET centre. The authorized users from registered colleges can access e-resources and download articles directly from the publisher's website once they are duly authenticated as authorized users through servers deployed at the INFLIBNET centre.

\section{About N-LIST Consortium:}

The National Library and Information Service Infrastructure for scholarly content (N-LIST) is an initiation of the ministry of human resources development (MHRD) launched on 4 May 2010 and now being funded by UGC, as a college component under e-ShodhSindu consortium. From 2014 onwards, N-LIST programme is subsumed under e-ShodhSindu. (INFLIBNET, n.d.-a) The programme provides access to selected e-resources for all government-aided colleges under section $2 \mathrm{~F} / 12 \mathrm{~B}$ of UGC act and non-aided colleges except for colleges imparting education in agriculture, engineering, management, medical, pharmacy, dentistry and nursing. As on 25 September 2021, a total number of 3159 government/ government-aided colleges covered under the section $12 \mathrm{~B}$ of UGC Act and 237 non-aided colleges have registered in N-LIST programme (INFLIBNET, n.d.-c). State-wise subscription data indicates that, among the Indian states Maharashtra is the most aware state (with 748 subscription) followed by Karnataka (414) \& Tamil Nadu (288) (INFLIBNET, n.d.-d). For registration of new colleges and renewal of member colleges, the annual membership fee for aided colleges is Rs. 5900/- while the same for non-aided colleges is Rs. 35,400/(INFLIBNET, n.d.-b). Member colleges can access for 6,000+ e-journals and 31,35,000+e-books through the N-LIST platform (INFLIBNET, n.d.-e).

N-LIST programme was launched to nurture research scholars and college students (mainly PG-students) by providing access to knowledge resources in various disciplines at their own place. Through the N-LIST consortium, the University Grant Commission (UGC) is investing a significant amount of money in providing appropriate and up-to-date electronic information sources for the benefit of our country's college academic community. But the concern is whether the user community is taking advantage of the e-resources to their full potential or not. In this context, an attempt is made in the present study to investigate the effectiveness and usefulness of N-LIST e-resources among postgraduate students in the Punjab area.

\section{Review of Literature:}

To determine the scope of the N-LIST consortium's implementation, Sinha et al. (2013) investigated the current state of ICT and Internet literacy skills among college library users. Ten college libraries in South Assam's Barak Valley having access to the N-LIST consortium were chosen for the study $\left(n_{d}=200 \& n_{v}=153\right)$. George et al. (2014) aimed to ascertain the awareness of the N-LIST programme among science and social science teachers of selected colleges, understand the usage pattern and preferences, level of satisfaction, the need for orientation programmes and the various suggestions put forward by the users. Chikkamanju and Kumbar (2015) conducted a study to investigate the purpose of use, types of services, level of satisfaction, problems encountered while accessing, training/ orientation programme, and preferred external storage medium for 
storing information resources via N-LIST services. The study was carried out with Arts, Commerce, and Science discipline first-year colleges affiliated with Tumkur University $(n=1706)$. Nagesh and Naveen (2016) focused their research on the N-LIST subscription status at Govt. first-grade college (GFG) libraries in Hassan district and also emphasize the issues and problems of subscribing and accessing N-LIST in the libraries. Instead of limiting the sample, the study covers all 24 GFG college libraries in Hassan. Narayanaswamy (2016) investigated the use and knowledge of N-LIST Services by students and staff members of selected Degree College libraries affiliated with Bangalore University $(\mathrm{n}=15)$. A systematic questionnaire and interview procedure were used to obtain data for the survey. This study depicts that for effective use of N-LIST e-resource services, adequate user awareness/orientation programmes, workshops, and other activities are required. Dhuri \& Lobo (2021) explored the usage of the e-resources (both e-journals \& e-books) provided by the N-LIST consortium from the library users (students, research scholars and the faculty) of the academic colleges across Goa by conducting a short-online survey through Google form questionnaire. The study findings demonstrated that N-LIST e-resources were critical in meeting users' information needs throughout the Covid-19 pandemic. To examine the awareness about the N-LIST consortium in Tamilnadu state, Subbiah (2019) surveyed the state-affiliated colleges (Govt college, Autonomous, Aided college \& Self-finance college) and their subscription status, usage \& benefits. According to the research, approximately 256 affiliated colleges have subscribed to the N-LIST in the last nine years (2009 to 2017). Hanchinal (2019) attempted to assess the use of electronic resources, particularly the N-LIST programme by the college students of the Mumbai Suburban area. A structured questionnaire was distributed to 300 respondents, 200 completed questionnaires were received, and the collected data were evaluated. The study's key findings revealed that only half of the respondents use N-LIST Program e-resources, while the other half do not use or are unaware of them. Again, Anjuma (2017) briefly described the use and awareness of the N-LIST Programme, its uses and the problem faced by the Graduate Students of Mariani College, J.B. College and C.K.B. Commerce College of Jorhat District, Assam. In a similar study, Kaur (2018) examined the purpose usage of N-LIST by faculty members and PG students of Kamla Nehru College for Women, a survey was conducted through questionnaires. Fifty questionnaires were distributed to each type of respondent, and the replies were analysed using human computations.

\section{Study Objectives:}

The present study is an endeavour to investigate the usage and accessibility of N-LIST e-resources by postgraduate students in Govt. aided colleges in Punjab.

The study was conducted with the following objectives:

(i) To analyse the awareness level and sources of information about N-LIST e-resources among postgraduate students.

(ii) To study the frequency and purpose of the usage of N-LIST e-resources by postgraduate students.

(iii) To identify the types of used e-resources \& maximum used e-resources in N-LIST consortium by postgraduate students.

(iv) To analyze the student's satisfaction level of the N-LIST resources for improving their learning outcomes.

(v) To analyze the problems faced by students in accessing N-LIST e-resources. 


\section{Methodology:}

The survey of the study conducted using a structured questionnaire method build with the help of Google Form and distributed (both print \& online medium to the targeted Post Graduate students of Government Aided colleges in Punjab region. The study targeted 30 Government Aided colleges in Punjab which has the access of N-LIST e-resources. Among this 30 colleges, 23 Arts \& Social Science, 12 Science \& 15 Commerce departments are covered in this study. Out of them, 15 Arts \& Social Science, 12 Science \& 8 Commerce departments respond with minimum of 1 response from that particular departments.

\begin{tabular}{|c|c|c|c|c|}
\hline \multirow{2}{*}{ Types } & \multicolumn{3}{|c|}{ Departments Covered } & College \\
Covered
\end{tabular}

Table 1: Target Colleges Departments Covered under the Study

Now if the target samples take into account, exact 450 questionnaires distributed among 450 students of 30 covered colleges, and among them 318 respondents responses, with a response rate of $70.67 \%$. As, additional assistance was given to the targeted students while filling up the questionnaire and any wrongly filled questionnaire was asked to revised from the students, this 318 questionnaire was finalized as valid study sample of the present research.

\begin{tabular}{|l|c|c|c|}
\hline Discipline & $\begin{array}{c}\text { No. of } \\
\text { Questionnaire } \\
\text { Distributed }\end{array}$ & $\begin{array}{c}\text { No. of Responses } \\
\text { Received }\end{array}$ & $\begin{array}{c}\text { Rate of Response } \\
\text { (in percentage) }\end{array}$ \\
\hline Arts/Social Science & 150 & 106 & 70.67 \\
\hline Science & 150 & 123 & 82.00 \\
\hline Commerce & 150 & 89 & 59.33 \\
\hline Total & $\mathbf{4 5 0}$ & $\mathbf{3 1 8}$ & $\mathbf{7 0 . 6 7}$ \\
\hline
\end{tabular}

Table 2: Discipline-wise Questionnaire Distribution \& Response Received

\section{Results \& Discussion:}

\section{Awareness about N-LIST Consortium}

Only by being aware of N-LIST a user can utilize its e-resources at an optimum benefit. Respondents were asked to state whether or not they were aware of N-LIST e-resources in order to gauge their awareness.

\begin{tabular}{|l|c|c|}
\hline Discipline & Yes & No \\
\hline
\end{tabular}




\begin{tabular}{|l|c|c|}
\hline Arts/Social Science & 68 & 38 \\
& $(64.15 \%)$ & $(35.85 \%)$ \\
\hline Science & 114 & 7 \\
& $(92.68 \%)$ & $(7.32 \%)$ \\
\hline Commerce & 59 & 30 \\
& $(66.29 \%)$ & $(33.71 \%)$ \\
\hline Total & $\mathbf{2 4 1}$ & $\mathbf{7 5}$ \\
& $\mathbf{( 7 5 . 7 9 \% )}$ & $\mathbf{( 2 4 . 2 1 \% )}$ \\
\hline
\end{tabular}

Table 3: Awareness about N-LIST Consortium

Table 3 shows that the vast majority of the students (241 or $75.79 \%$ ) were aware of N-LIST e-resources, while a minor portion was unaware (75 or $24.21 \%$ ). According to the different disciplines, $64.15 \%$ of Arts students, $92.68 \%$ of Science students and $66.29 \%$ of Commerce students were aware of N-LIST e-resources. The results of the study indicate that N-LIST is widely popular among college students.

\subsection{Sources of Information about N-LIST Consortium}

Information sources to get aware about N-LIST consortium can be more than one. In this question PG-students pick more than one response to identify their information source from the below mentioned seven (7) sources of information. Here targeted PG-students are those who aware about N-LIST e-resources [i.e. for this question $n=241(100 \%)$ ].

\begin{tabular}{|c|c|c|c|c|}
\hline $\begin{array}{l}\text { Sources of } \\
\text { Information }\end{array}$ & $\begin{array}{l}\text { Arts/Social } \\
\text { Science }\end{array}$ & Science & Commerce & $\begin{array}{c}\text { Total } \\
(n=241)\end{array}$ \\
\hline Institute's website & $\begin{array}{c}9 \\
(13.24 \%)\end{array}$ & $\begin{array}{c}32 \\
(28.07 \%)\end{array}$ & $\begin{array}{c}4 \\
(6.78 \%)\end{array}$ & $\begin{array}{c}45 \\
(18.67 \%)\end{array}$ \\
\hline Institute's prospectus & $\begin{array}{c}0 \\
(0.00 \%) \\
\end{array}$ & $\begin{array}{c}13 \\
(11.40 \%) \\
\end{array}$ & $\begin{array}{c}0 \\
(0.00 \%)\end{array}$ & $\begin{array}{c}13 \\
(5.39 \%) \\
\end{array}$ \\
\hline $\begin{array}{l}\text { Class teachers or } \\
\text { other faculty members }\end{array}$ & $\begin{array}{c}61 \\
(89.71 \%)\end{array}$ & $\begin{array}{c}114 \\
(100.00 \%)\end{array}$ & $\begin{array}{c}28 \\
(47.46 \%)\end{array}$ & $\begin{array}{c}203 \\
(84.23 \%)\end{array}$ \\
\hline $\begin{array}{l}\text { Library orientation } \\
\text { program }\end{array}$ & $\begin{array}{c}47 \\
(69.12 \%)\end{array}$ & $\begin{array}{c}94 \\
(82.46 \%)\end{array}$ & $\begin{array}{c}37 \\
(62.71 \%)\end{array}$ & $\begin{array}{c}178 \\
(73.86 \%)\end{array}$ \\
\hline Library staff & $\begin{array}{c}53 \\
(77.94 \%) \\
\end{array}$ & $\begin{array}{c}88 \\
(77.19 \%) \\
\end{array}$ & $\begin{array}{c}43 \\
(72.88 \%) \\
\end{array}$ & $\begin{array}{c}184 \\
(76.35 \%) \\
\end{array}$ \\
\hline $\begin{array}{l}\text { Classmates or other } \\
\text { students }\end{array}$ & $\begin{array}{c}34 \\
(50.00 \%)\end{array}$ & $\begin{array}{c}60 \\
(52.63 \%)\end{array}$ & $\begin{array}{c}52 \\
(88.14 \%)\end{array}$ & $\begin{array}{c}146 \\
(60.58 \%)\end{array}$ \\
\hline Library notice board & $\begin{array}{c}14 \\
(20.59 \%)\end{array}$ & $\begin{array}{c}36 \\
(31.58 \%)\end{array}$ & $\begin{array}{c}7 \\
(11.86 \%)\end{array}$ & $\begin{array}{c}57 \\
(23.65 \%)\end{array}$ \\
\hline
\end{tabular}

*Shaded area denotes the most preferred sources of information for each subject discipline

Table 4: Sources of Information about N-LIST Consortium

Table 4 revels that majority of the PG-students aware about N-LIST consortium from "Class teachers or other faculty members" (203 or $84.23 \%$ ). It is followed by the information received from "Library staff", "Library orientation program" \& "Classmates or other students" with a 
coverage of $76.35 \%$ (184), 73.86\% (178) \& 60.58\% (146) respectively. "Institute's prospectus" with $5.39 \%$ (13) coverage is the least popular sources of information.

\section{Use of N-LIST E-Resources}

Awareness of N-LIST e-resources does not always confirm its use. But it is necessary for the PG-students to take the ultimate benefits of N-LIST e-resources that provides relevant and up-to-date electronic resources for the benefit of the college academic community in India. To achieve the maximum learning outcome, the effective and efficient utilization of these resources are required.

\begin{tabular}{|l|c|c|}
\hline Discipline & Yes & No \\
\hline \multirow{2}{*}{ Arts/Social Science } & 57 & 49 \\
& $(53.77 \%)$ & $(46.23 \%)$ \\
\hline \multirow{2}{*}{ Science } & 111 & 12 \\
& $(96.24 \%)$ & $(9.76 \%)$ \\
\hline \multirow{2}{*}{ Commerce } & 53 & 36 \\
& $(59.55 \%)$ & $(40.45 \%)$ \\
\hline \multirow{2}{*}{ Total } & $\mathbf{2 2 1}$ & $\mathbf{9 7}$ \\
& $\mathbf{( 6 9 . 5 0 \% )}$ & $\mathbf{( 3 0 . 5 0 \% )}$ \\
\hline
\end{tabular}

Table 5: Discipline-wise Use Percentage of N-LIST E-resources

Table 5 depicts the use of N-LIST e-resources by postgraduate students in the arts, science and commerce streams. According to the survey result, the maximum percentage of the students $(69.50 \%)$ confirms their use of N-LIST e-resources, while a few students (30.50\%) do not. Among the users, 53.77\% are from the Arts stream, 96.24\% from Science and 59.55\% from Commerce. The data of actual users is selected as the target sample for further analysis.

\subsection{Frequency of Use of N-LIST E-Resource}

As the access to e-resources is not limited by the time constrain, the resources of N-LIST provides access to quality e-resources at anytime and anywhere. In this question, the respondents were asked to mention how often they used N-LIST e-resources.

\begin{tabular}{|c|c|c|c|c|}
\hline Frequency & $\begin{array}{c}\text { Arts \& Social } \\
\text { Science } \\
(\mathbf{n = 5 7 )}\end{array}$ & $\begin{array}{c}\text { Science } \\
(\mathbf{n}=\mathbf{1 1 1})\end{array}$ & $\begin{array}{c}\text { Commerce } \\
(\mathbf{n}=\mathbf{5 3})\end{array}$ & $\begin{array}{c}\text { Total } \\
\mathbf{( n = 2 2 1 )}\end{array}$ \\
\hline Daily & 4 & 14 & 0 & $\mathbf{1 8}$ \\
$(7.02 \%)$ & $(12.61 \%)$ & $(0.00 \%)$ & $\mathbf{( 8 . 1 4 \% )}$ \\
\hline Once in a week & 11 & 65 & 19 & $\mathbf{9 5}$ \\
Monthly & $(19.30 \%)$ & $(58.56 \%)$ & $(35.85 \%)$ & $\mathbf{( 4 2 . 9 9 \% )}$ \\
\hline Occasionally & 24 & 13 & 27 & $\mathbf{6 4}$ \\
& $(42.11 \%)$ & $(11.71 \%)$ & $(50.94 \%)$ & $\mathbf{( 2 8 . 9 6 \% )}$ \\
\hline
\end{tabular}

*Shaded area denotes the majority frequency level of usage N-LIST consortium in each discipline 


\section{Table 6: Frequency of Use N-LIST E-resources}

According to Table 6, the majority of the arts \& social science (42.11\%) and commerce (50.94\%) students use N-LIST e-resources monthly. In the case of the science stream, the majority of the students $(58.56 \%)$ uses N-LIST e-resources at least once in a week. When it comes to total utilization, the majority of the students (95 or $42.99 \%$ ) use N-LIST e-resources at least once in a week with a small percentage $(8.14 \%)$ using them everyday.

\subsection{Place of Access of N-LIST E-Resources}

In the questionnaire, this question deals with the commonly favourable place of the users for access N-LIST e-resources. According to the N-LIST consortium, users can access N-LIST e-resources from the college library, their particular department, college computer centre/lab, and even from their home with login id \& password.

\begin{tabular}{|c|c|c|c|c|}
\hline Place of access & $\begin{array}{c}\text { Arts \& Social } \\
\text { Science }\end{array}$ & Science & Commerce & Total \\
\hline Library & $\begin{array}{c}37 \\
(64.91 \%)\end{array}$ & $\begin{array}{c}101 \\
(90.99 \%)\end{array}$ & $\begin{array}{c}12 \\
(22.64 \%)\end{array}$ & $\begin{array}{c}\mathbf{1 7 0} \\
\mathbf{( 7 6 . 9 2 \% )}\end{array}$ \\
\hline Home & 54 & 111 & 53 & $\mathbf{2 1 8}$ \\
$(94.74 \%)$ & $(100.00 \%)$ & $(100.00 \%)$ & $\mathbf{( 9 8 . 6 4 \% )}$ \\
\hline Department & 23 & 55 & 3 & $\mathbf{8 1}$ \\
\hline College computer & $(40.35 \%)$ & $(49.55 \%)$ & $(5.6 \%)$ & $\mathbf{( 3 6 . 6 5 \% )}$ \\
center/Lab & 8 & 29 & 0 & $\mathbf{3 7}$ \\
\hline
\end{tabular}

$*$ Shaded area denotes the favourite place of usage of N-LIST consortium

Table 7: Discipline-wise Place of Access of N-LIST E-Resources

In response to this multi-selection question, out of 221 respondents $218(98.64 \%)$ respondents prefer their home, followed by $76.92 \%$ of the students who use N-LIST e-resources from the college library, $36.65 \%$ of students access from departments and only very few percentages $(16.74 \%)$ of students access from the college computer centre/lab.

\subsection{Purpose of Use of N-LIST E-Resources}

The use of N-LIST e-resources varied upon the different requirements of PG students. Taking this into account, this closed-ended question was constructed by stating the six most prominent purposes for which N-LIST e-resources were used to their full potential.

\begin{tabular}{|l|c|c|c|c|c|}
\hline Purpose & $\begin{array}{c}\text { Strongly } \\
\text { agree }\end{array}$ & Agree & $\begin{array}{c}\text { Neither agree } \\
\text { nor disagree }\end{array}$ & Disagree & $\begin{array}{c}\text { Strongly } \\
\text { disagree }\end{array}$ \\
\hline
\end{tabular}




\begin{tabular}{|l|c|c|c|c|c|}
$\begin{array}{l}\text { Preparation of } \\
\text { assignment }\end{array}$ & $\begin{array}{c}42 \\
(19.00 \%)\end{array}$ & $\begin{array}{c}113 \\
(51.13 \%)\end{array}$ & $\begin{array}{c}33 \\
(14.93 \%)\end{array}$ & $\begin{array}{c}27 \\
(12.22 \%)\end{array}$ & $\begin{array}{c}6 \\
(2.71 \%)\end{array}$ \\
\hline $\begin{array}{l}\text { Preparation seminar/ } \\
\text { presentation }\end{array}$ & $\begin{array}{c}33 \\
(14.93 \%)\end{array}$ & $\begin{array}{c}52 \\
(23.53 \%)\end{array}$ & $\begin{array}{c}104 \\
(47.06 \%)\end{array}$ & $\begin{array}{c}30 \\
(13.57 \%)\end{array}$ & $\begin{array}{c}2 \\
(0.90 \%)\end{array}$ \\
\hline $\begin{array}{l}\text { For project/ } \\
\text { dissertation }\end{array}$ & $\begin{array}{c}70 \\
(31.67 \%)\end{array}$ & $\begin{array}{c}144 \\
(65.16 \%)\end{array}$ & $\begin{array}{c}4 \\
(1.81 \%)\end{array}$ & $\begin{array}{c}3 \\
(1.36 \%)\end{array}$ & $\begin{array}{c}0 \\
(0.00 \%)\end{array}$ \\
\hline $\begin{array}{l}\text { For preparing personal } \\
\text { notes }\end{array}$ & $\begin{array}{c}27 \\
(12.22 \%)\end{array}$ & $(44.80 \%)$ & $(26.24 \%)$ & $(11.76 \%)$ & $(4.98 \%)$ \\
\hline $\begin{array}{l}\text { Preparing for } \\
\text { competitive } \\
\text { examinations }\end{array}$ & 16 & 91 & 108 & 5 & 1 \\
\hline For update knowledge & $(7.24 \%)$ & $(41.18 \%)$ & $(48.87 \%)$ & $(2.26 \%)$ & $(0.45 \%)$ \\
\hline
\end{tabular}

*Shaded area denotes the level of usage in each purpose (among 5 point likert-scale)

Table 8: Purpose of Use N-LIST E-Resources

Table 8 depicts that the majority of postgraduate students (68.33\%) agreed that N-LIST e-resources were used for their knowledge updation and preparation of project/ dissertation (65.16\%). More than half of the students $(51.13 \%)$ agreed that N-LIST e-resources were used for preparing their assignments. Below half of the students used the resources for preparing personal notes $(44.80 \%)$ and preparing for competitive examinations (41.18\%). Among the six pre-decided purposes, maximum disagreement was observed in the case of preparation seminar/ presentation $(13.57 \%)$ followed by preparation of assignment (12.22\%). Again, a maximum of 31.67\% strongly agreed with the use of N-LIST e-resources for preparation seminar/presentation, in opposite maximum strongly disagreement noticed for preparing personal notes $(4.98 \%)$.

\subsection{Types of Used E-Resources:}

E-journals and e-books are the most frequently used e-resources in the N-LIST consortium among PG students. This questionnaire question addresses the question of which of the two e-resources is more often used.

\begin{tabular}{|l|c|c|c|c|}
\hline E-Resources & Arts \& Social Science & Science & Commerce & Total \\
\hline E-journals & 53 & 111 & 50 & $\mathbf{2 1 4}$ \\
$(89.83 \%)$ & $(100.00 \%)$ & $(94.34 \%)$ & $\mathbf{( 9 6 . 8 3 \% )}$ \\
\hline E-books & 29 & 44 & 31 & $\mathbf{1 0 4}$ \\
& $(49.15 \%)$ & $(39.64 \%)$ & $(58.49 \%)$ & $\mathbf{( 4 7 . 0 6 \% )}$ \\
\hline
\end{tabular}

Table 9: Discipline-wise Used E-Resource Type

Table 9 shows that $100 \%$ of science student, most of the commerce (94.34\%) and arts \& social science $(89.83 \%)$ preferred e-journal. But, only in the case of commerce students the use of e-books crosses half $(58.49 \%)$. Table 9 highlighted e-journals are the better-used e-resources compared to e-books. 


\subsubsection{Most Used E-Resources in N-LIST Consortium:}

Among the e-books \& e-journals, some specific ones have been used by the PG students most frequently. This question seeks to identify the name of the sources which is used most among different disciplines.

\begin{tabular}{|l|c|c|c|c|}
\hline \multicolumn{1}{|c|}{ E-Journals } & $\begin{array}{c}\text { Arts \& Social } \\
\text { Science } \\
(\mathbf{n = 5 3 )}\end{array}$ & $\begin{array}{c}\text { Science } \\
\mathbf{( n = 1 1 1 )}\end{array}$ & $\begin{array}{c}\text { Commerce } \\
(\mathbf{n = 5 0 )}\end{array}$ & $\begin{array}{c}\text { Total } \\
\mathbf{( n = 2 1 4 )}\end{array}$ \\
\hline American Institute of & 0 & 53 & 0 & 53 \\
Physics & $(0.00 \%)$ & $(47.75 \%)$ & $(0.00 \%)$ & $(24.77 \%)$ \\
\hline Annual Reviews & 0 & 46 & 0 & 46 \\
$(0.00 \%)$ & $(41.44 \%)$ & $(0.00 \%)$ & $(21.50 \%)$ \\
\hline Economics and Political & 32 & 17 & 48 & 97 \\
Weekly & $(54.24 \%)$ & $(15.32 \%)$ & $(90.57 \%)$ & $(45.33 \%)$ \\
\hline Indian Journals & 50 & 108 & 50 & 208 \\
\hline Institute of Physics & $(94.34 \%)$ & $(97.30 \%)$ & $(100.00 \%)$ & $(97.20 \%)$ \\
\hline JSTOR & 0 & 59 & 13 & 72 \\
\hline Oxford University Press & $(0.00 \%)$ & $(53.15 \%)$ & $(24.53 \%)$ & $(33.64 \%)$ \\
\hline Royal Society of Chemistry & $(47.46 \%)$ & $(100.00 \%)$ & $(33.96 \%)$ & $(73.36 \%)$ \\
\hline H.W. Wilson & $(0.00 \%)$ & $(39.64 \%)$ & $(0.00 \%)$ & $(20.56 \%)$ \\
\hline Cambridge University Press & $(23.73 \%)$ & $(61.26 \%)$ & $(7.55 \%)$ & $(40.19 \%)$ \\
\hline
\end{tabular}

*Shaded area denotes the most used E-resources of the particular stream

\section{Table 10: Most Used E-Journals in N-LIST Consortium}

Due to multiple options, the overall percentage exceeds $100 \%$. As shown in Table 10, the majority of postgraduate students from Arts \& Social Science $(94.34 \%)$ and Commerce $(100.00 \%)$ stream preferred Indian Journals in e-journals, followed by JSTOR $(59.32 \% \& 92.45 \%$, respectively). While the students of Science stream preferred journals from Oxford University Press $(100.00 \%)$ a little higher than Indian Journals (97.30\%). Overall, Indian Journals are the most used e-journals (97.20\%) in the N-LIST e-consortium.

\begin{tabular}{|c|c|c|c|c|}
\hline E-Books & $\begin{array}{c}\text { Arts \& Social } \\
\text { Science } \\
(\mathbf{n}=\mathbf{2 9})\end{array}$ & $\begin{array}{c}\text { Science } \\
\mathbf{( n = 4 4 )}\end{array}$ & $\begin{array}{c}\text { Commerce } \\
(\mathbf{n}=\mathbf{3 1})\end{array}$ & $\begin{array}{c}\text { Total } \\
(\mathbf{n}=\mathbf{1 0 4})\end{array}$ \\
\hline Cambridge Books Online & $\begin{array}{c}16 \\
(55.17 \%)\end{array}$ & $\begin{array}{c}28 \\
(63.64 \%)\end{array}$ & $\begin{array}{c}0 \\
(0.00 \%)\end{array}$ & $\begin{array}{c}44 \\
(42.31 \%)\end{array}$ \\
\hline
\end{tabular}




\begin{tabular}{|l|c|c|c|c|}
\hline E-brary & $\begin{array}{c}28 \\
(96.55 \%)\end{array}$ & $\begin{array}{c}35 \\
(79.55 \%)\end{array}$ & $\begin{array}{c}27 \\
(87.10 \%)\end{array}$ & $\begin{array}{c}90 \\
(86.54 \%)\end{array}$ \\
\hline EBSCOhost-Net Library & 0 & 44 & 19 & 63 \\
$(0.00 \%)$ & $(100.00 \%)$ & $(61.29 \%)$ & $(60.58 \%)$ \\
\hline Hindustan Book Agency & 0 & 27 & 0 & 27 \\
$(0.00 \%)$ & $(61.36 \%)$ & $(0.00 \%)$ & $(25.96 \%)$ \\
\hline Institute of South East Asian & 24 & 9 & 0 & 33 \\
Studies(ISEAS) books & $(82.76 \%)$ & $(20.45 \%)$ & $(0.00 \%)$ & $(31.73 \%)$ \\
\hline Oxford Scholarship & 29 & 38 & 0 & 67 \\
\hline Springer eBooks & $(100.00 \%)$ & $(86.36 \%)$ & $(0.00 \%)$ & $(64.42 \%)$ \\
\hline Mylibrary-McGraw Hill & 26 & 41 & 31 & 98 \\
& $(89.66 \%)$ & $(93.18 \%)$ & $(100.00 \%)$ & $(94.23 \%)$ \\
\hline World-ebooks Library & 21 & 10 & 15 & 46 \\
\hline South Asia Archive & $(72.41 \%)$ & $(22.73 \%)$ & $(48.39 \%)$ & $(44.23 \%)$ \\
\hline
\end{tabular}

* Shaded area denotes the most used E-resources of the particular stream

Table 11: Most Used E-Books in N-LIST Consortium

Similarly, Oxford Scholarship was the most used e-books by Arts \& Social Science students, while EBSCOhost-Net Library was preferred most by the Science students (100.00\%) and Springer eBooks by the Commerce students $(100.00 \%)$. Despite not being top-usage by any particular stream, E-brary manages to get the overall most usage stats $(86.54 \%)$ among the e-books in the N-LIST consortium.

\subsection{Level of Satisfaction of Sources Available in N-LIST Consortium}

N-LIST consortium provides online information in the form of e-books and e-journals. These e-resources are used to improve the learning outcomes of PG-students in colleges. So to analyse the satisfaction levels of N-LIST e-resources among students, in this questionnaire, five points Likert scale is used starting with extremely satisfied to not satisfied at all and the recorded responses tabulated below in table 12 .

\begin{tabular}{|c|c|c|c|c|c|}
\hline $\begin{array}{c}\text { Retrieved information } \\
\text { includes }\end{array}$ & 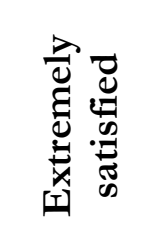 & 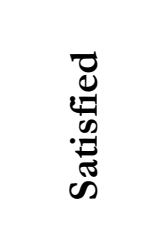 & 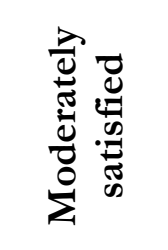 & 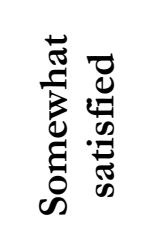 & 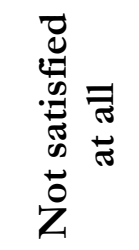 \\
\hline Subject coverage & $\begin{array}{c}14 \\
(6.33 \%)\end{array}$ & $\begin{array}{c}132 \\
(59.73 \%)\end{array}$ & $\begin{array}{c}55 \\
(24.89 \%)\end{array}$ & $\begin{array}{c}17 \\
(7.69 \%)\end{array}$ & $\begin{array}{c}3 \\
(1.36 \%)\end{array}$ \\
\hline
\end{tabular}




\begin{tabular}{|l|c|c|c|c|c|}
\hline $\begin{array}{l}\text { Relevance of learning } \\
\text { materials according to course } \\
\text { disciplines }\end{array}$ & $\begin{array}{c}11 \\
(4.98 \%)\end{array}$ & $\begin{array}{c}91 \\
(41.18 \%)\end{array}$ & $\begin{array}{c}83 \\
(37.56 \%)\end{array}$ & $\begin{array}{c}26 \\
(11.76 \%)\end{array}$ & $\begin{array}{c}10 \\
(4.52 \%)\end{array}$ \\
\hline Quality of contents & $\begin{array}{c}19 \\
(8.60 \%)\end{array}$ & $\begin{array}{c}105 \\
(47.51 \%)\end{array}$ & $\begin{array}{c}72 \\
(32.58 \%)\end{array}$ & $\begin{array}{c}20 \\
(9.05 \%)\end{array}$ & $\begin{array}{c}5 \\
(2.26 \%)\end{array}$ \\
\hline $\begin{array}{l}\text { Availability of updated } \\
\text { information }\end{array}$ & $\begin{array}{c}22 \\
(9.95 \%)\end{array}$ & $\begin{array}{c}45 \\
(20.36 \%)\end{array}$ & $\begin{array}{c}123 \\
(55.66 \%)\end{array}$ & $\begin{array}{c}29 \\
(13.12 \%)\end{array}$ & $\begin{array}{c}2 \\
(0.90 \%)\end{array}$ \\
\hline
\end{tabular}

$*$ Shaded area denotes the maximum value of the particular satisfaction level

\section{Table 12: Level of Satisfaction of Available N-LIST E-resources}

Table 12 demonstrates that the majority of students were satisfied with the subject coverage (59.73\%), the relevance of the learning material (41.18\%), and content quality $(47.51 \%)$ in N-LST e-resources, while the availability of updated information was somewhat satisfied (55.66\%). Again, maximum students are extremely satisfied with the content quality $(8.60 \%)$ but not at all satisfied with the relevance of the learning material (4.52\%).

\subsection{Problems while Using N-LIST E-Resources}

The optimal use of N-LIST e-resources is hampered by some issues in getting access to these resources. The respondents were asked to identify the problems they encountered while using N-LIST e-resources from a list of predetermined issues in this question, and the results are summarised and tabulated in table 13 below.

\begin{tabular}{|l|c|c|c|c|}
\hline Problems & $\begin{array}{c}\text { Arts \& Social } \\
\text { Sciences } \\
(\mathbf{n = 5 7 )}\end{array}$ & $\begin{array}{c}\text { Science } \\
(\mathbf{n = 1 1 1})\end{array}$ & $\begin{array}{c}\text { Commerce } \\
\mathbf{( n = 5 3 )}\end{array}$ & $\begin{array}{c}\text { Total } \\
\mathbf{( n = 2 2 1 )}\end{array}$ \\
\hline Lack of technical knowledge & $\begin{array}{c}57 \\
(100.00 \%)\end{array}$ & $\begin{array}{c}22 \\
(19.82 \%)\end{array}$ & $\begin{array}{c}46 \\
(86.79 \%)\end{array}$ & $\begin{array}{c}125 \\
(56.56 \%)\end{array}$ \\
\hline $\begin{array}{l}\text { Provide irrelevant } \\
\text { information }\end{array}$ & $\begin{array}{c}49 \\
(85.96 \%)\end{array}$ & $\begin{array}{c}84 \\
(75.68 \%)\end{array}$ & $\begin{array}{c}50 \\
(94.34 \%)\end{array}$ & $\begin{array}{c}183 \\
(82.81 \%)\end{array}$ \\
\hline Language barrier & 52 & 36 & 38 & 126 \\
$(91.23 \%)$ & $(32.43 \%)$ & $(71.70 \%)$ & $(57.01 \%)$ \\
\hline Lack of library support & 27 & 35 & 31 & 93 \\
$(47.37 \%)$ & $(31.53 \%)$ & $(58.49 \%)$ & $(42.08 \%)$ \\
\hline $\begin{array}{l}\text { Not provide update } \\
\text { information }\end{array}$ & 28 & 67 & 24 & 119 \\
$(49.12 \%)$ & $(60.36 \%)$ & $(45.28 \%)$ & $(53.85 \%)$ \\
\hline
\end{tabular}

*Shaded area denotes the major problems face by the users of each stream

\section{Table 13: Commonly Faced Problems in using N-LIST Consortium}

According to table 13,100\% of arts \& social science students and a large majority of commerce $(86.79 \%)$ students face the problem of lack of technical knowledge in accessing N-LIST e-resources. Again, more than three-fourth students of each stream face huge problems due to the availability of a large amount of irrelevant information ( $A \& S=85.96 \%, S=75.68 \%, C=94.34 \%$ ), whereas the language barrier also causes problems for a large number of Arts \& Social Science (91.23\%) and 
Commerce $(71.70 \%)$ students. Overall, with $82.81 \%$, availability of irrelevant information is the major problem among the3 PG-students while accessing N-LIST e-resources.

\section{Major Findings of the Study:}

The following are some of the key findings of the current study that determine the effective completion of study objectives:

1. If the target respondents are considered, in the Punjab region the PG-students are mostly aware of the N-LIST consortium.

2. Class teachers or other faculty members are the most preferred source of information.

3. This study again confirms that awareness doesn't always assure uses. Though PG-students of the Punjab region are aware enough about the N-LIST e-resources but two-third uses N-LIST for their benefit.

4. Once-in-a-week and monthly is the most favourable usage frequency and most of the users use N-LIST e-resources from their home.

5. Among the e-resources, e-journals have a greater number of users than e-books.

6. Indian journals among the e-journals and e-brary among the e-books has maximum usage.

7. Most of the users are either satisfied or moderately satisfied after using N-LIST e-resources.

8. Availability of irrelevant information and lack of technical knowledge occurs some problem while using N-LIST e-resources.

\section{Conclusion:}

In the Indian education system, Colleges play a significant role as an intermediate to connect between School \& University level education. To grant special attention to college level education, UGC-MHRD introduces the N-LIST consortium to provide college students, research scholars and faculties an authentic source of e-resources that can help them in various purposes. The inclusion of consortium-based e-resources subscription has to lead the enhancement of quality education to their users. The present study evaluates the awareness, accessibility, usability, benefits \& difficulties of N-LIST resources among PG-students considered under the Punjab region. The study findings indicate that though the PG-students of the Punjab region are significantly aware of the N-LIST consortium, their willingness to use it for their benefits is limited. Further investigation clarifies that the presence of irrelevant information \& lack of technical knowledge are the prime reason behind this. To overcome it, in conclusion, it can be said that, besides awareness \& outreach programmes, college libraries should conduct hands-on-training programmes \& workshops to not only aware them but direct how to use them. 


\section{References:}

Anjuma, S. (2017). Use and Awareness about N-List E-Resources by the Graduate Students of Mariani College, J.B. College and C.K.B. Commerce College of Jorhat District, Assam: A Study-Indian Journals. Journal of Information Management, 4(1), 66-80. https:/ / www.indianjournals.com/ijor.aspx?target $=$ ijor:jim\&volume $=4 \& i s s u e=1 \&$ article $=00$ 7

Chikkamanju, \& Kumbar, M. (2015). Use of N-LIST Services by the students of First Grade Colleges in Tumkur District: A Survey. International Journal of Academic Library and Information Science, 3(7), 200-209. https://www.academicresearchjournals.org/IJALIS/PDF/2015/July/Chikkamanju\%20and $\% 20$ Kumbar.pdf

Dhuri, K., \& Lobo, J. (2021). N-LIST E-Resources: A Major Boon To The User Community During Covid-19 Pandemic Era: A Study. Library Philosophy and Practice (E-Journal). https://digitalcommons.unl.edu/libphilprac/4912

George, A., Pillai, M. G., \& PR, A. (2014). Use of N-LIST programme and the role of college librarians : a survey. https://core.ac.uk/download/pdf/33186529.pdf

Hanchinal, V. (2019). AWARENESS AND USAGE OF E-RESOURCES OF N-LIST CONSORTIUM: A STUDY WITH REFERENCE TO ACADEMIC COLLEGES OF MUMBAI. Library Philosophy and Practice (E-Journal). https://digitalcommons.unl.edu/libphilprac/2340

INFLIBNET. (n.d.-a). ABOUT N-LIST. Retrieved October 25, 2021, from https://nlist.inflibnet.ac.in/vabout.php

INFLIBNET. (n.d.-b). COLLEGE REGISTRATION | N-LIST. Retrieved October 25, 2021, from https://nlist.inflibnet.ac.in/vregister.php

INFLIBNET. (n.d.-c). MEMBER COLLEGE STATUS | N-LIST. Retrieved October 25, 2021, from https://nlist.inflibnet.ac.in/vstatus.php

INFLIBNET. (n.d.-d). Statewise Member Colleges Status | N-LIST. Retrieved October 25, 2021, from https://nlist.inflibnet.ac.in/vstatewise.php

INFLIBNET. (n.d.-e). SUBSCRIBED E-RESOURCES | N-LIST. Retrieved October 25, 2021, from https://nlist.inflibnet.ac.in/veresources.php

Kaur, G. (2018). USE OF N-LIST E- RESOURCES BY THE USERS OF GOVT. AIDED COLLEGE LIBRARY OF PHAGWARA. A STUDY. International Journal of Research and Analytical Reviews, 5(4), 295-298. http://ijrar.com/upload_issue/ijrar_issue_20542374.pdf 
Nagesh, R., \& Naveen, C. L. (2016). Status and Problems of N-List Consortia Subscription in Government First Grade Colleges of Hassan District, Karnataka: A Study. International Journal of Library and Information Studies, 6(2), 28-35. https://www.ijlis.org/abstract/status-and-problems-of-nlist-consortia-subscription-in-gover nment-first-grade-colleges-of-hassan-district-karnataka-a-st-69054.html

Narayanaswamy, B. V. (2016). Use and Awareness of N-List Services By Degree Colleges in Bangalore: A Study. International Research Journal of Multidisciplinary Science \& Technology, 1(5), 63-68. https://www.researchgate.net/publication/346602079

Sinha, M., Bhattacharjee, S., \& Bhattacharjee, S. (2013). ICT and Internet Literacy Skills for Accessing to E-Resources available under N-LIST Programme : A Case Study of College Library Users of Barak Valley, South Assam. Library Philosophy and Practice (E-Journal). https://digitalcommons.unl.edu/libphilprac/948

Subbiah, S. (2019). STATISTICAL OUT LOOK ON ACADEMIC SUBSCRIPTION TO THE N-LIST TAMILNADU STATE UNIVERSITIES AFFILIATED COLLEGES. Library Philosophy and Practice (E-Journal). https://digitalcommons.unl.edu/libphilprac/2830

The World Bank. (2020a). Education | Data - School Enrollment, primary (\% gross). https://data.worldbank.org/topic/4

The World Bank. (2020b). GDP per capita (current US\$) - China, India | Data. https://data.worldbank.org/indicator/NY.GDP.PCAP.CD?locations=CN-IN 